\title{
Efektivitas Metode Problem Solving dengan Model Polya terhadap Hasil Belajar Peserta Didik dalam Menyelesaikan Soal Cerita Matematika
}

\author{
Ernawati $^{1}$, Pertiwi Indah Lestari ${ }^{2}$ \\ 1, 2 Universitas Muslim Maros \\ 1 ernafajar1305@gmail.com \\ 2 pertiwi.earth@gmail.com
}

\begin{abstract}
ABSTRAK
Penelitian ini adalah penelitian Pre-Experimental. Dengan tujuan untuk mengerahui apakah metode problem solving model polya efektif terhadap hasil belajar siswa dalam menyelesaiakan soal cerita matematika. Adapun rancangan penelitian ini berbentuk One Group Pretest-Posttest Design dengan menggunakan perlakuan pada objek penelitian dengan melibatkan satu kelas saja sebagai kelas eksperimen tanpa variabel kontrol. Penelitian ini dilaksanakan pada semester genap tahun ajaran 2018/2019 tepatnya pada bulan Februari - April 2019. Penelitian ini dilaksanakan di SMA Negeri 11 Maros Baru. Berdasarkan hasil penelitian yang telah dilakukan diperoleh bahwa aktivitas siswa selama pembelajaran menggunakan metode problem solving model Polya dalam menyelesaikan soal cerita matematika dikategorikan aktif, untuk kemampuan guru dalam mengelola pembelajaran menggunakan metode problem solving model Polya dikatakan baik, respon siswa terhadap pembelajaran menggunakan metode problem solving model Polya dalam menyelesaikan soal cerita matematikadikategorikan positif, sedangkan untuk hasil ketuntasan siswa secara klasikal pada pembelajaran yang menggunakan metode problem solving model Polya dalam menyelesaikan soal cerita matematikajuga dikategorikan tuntas. Sesuai dengan syarat keefektifan pembelajaran yaitu suatu pembelajaran dikatakan efektif jika dari empat aspek yang ditentukan telah dipenuhi, dengan syarat satu dan empat harus dipenuhi, maka dari uraian hasil penelitian dan pembahasan diatas dapat dikatakan bahwa pembelajaran menggunakan metode problem solving model Polya dalam menyelesaikan soal cerita matematikapada materi pokok persamaan linear tiga variabel kelas X SMA Negeri 11 Maros Baru dikatakan efektif.
\end{abstract}

Kata Kunci: Metode Problem Solving, Model Polya, Efektifitas.

\begin{abstract}
This research is a Pre-Experimental study. With the aim of knowing whether the method of problem solving in the Polya model is effective against student learning outcomes in solving mathematical story problems. The design of this research is in the form of One Group PretestPosttest Design using treatment of the research object by involving only one class as an experimental class without control variables. This research was conducted in the even semester of the 2018/2019 school year precisely in February - April 2019. The research was carried out at 11 State High School Maros Baru. Based on the results of research that has been done, it is found that student activities during learning using the Polya model problem solving method in solving mathematical story problems are categorized active, for the teacher's ability to manage learning using the Polya model problem solving method is said to be good, students' responses to learning using the problem solving model method Polya in solving positive mathematical story problems is categorized positively, while for students' classical mastery results in learning using Polya's model problem solving methods in solving mathematical story problems are also categorized as complete. In accordance with the terms of the effectiveness of learning that is a learning said to be effective if of the four specified aspects have been met, with conditions one and four must be
\end{abstract}


met, then from the description of the results of the research and discussion above can be said that learning uses Polya's model problem solving methods in solving mathematical story problems the subject matter of the linear equations of the three variables of class X SMA Negeri 11 Maros Baru is said to be effective.

Keywords: Problem Solving Method, Polya Model, Effectiveness.

\section{A. PENDAHULUAN}

Matematika merupakan salah satu bidang studi yang menduduki peranan penting dalam pendidikan karena matematika tidak terlepas dari kehidupan manusia sehari-hari. Matematika juga merupakan salah satu mata pelajaran yang wajib dan diajarkan disetiap jenjang pendidikan. Pembelajaran matematika bertujuan untuk mengarahkan siswa untuk dapat memahami dan menguasai konsep, dalil, teorema, generalisasi dan matematika secara menyeluruh. Selanjutnya siswa juga diharapkan mampu berfikir logis, kritis, sistematis. Permasalahan yang dikaji dalam pembelajaran matematika pada umunya disajikan dalam bentuk soal-soal yang berupa pemecahan masalah. Sehingga diperlukan adanya kemampuan memecahkan masalah matematika. (Setiyowati, Wijonarko, \& Sulianto, 2018)

Berdasarkan informasi dari guru matematika kelas X di SMA Negeri 11 Maros Baru, kemampuan siswa dalam memecahkan masalah matematika masih rendah, sehingga berpengaruh pada hasil belajar siswa. Meskipun dalam penerapan pembelajaran matematika guru sudah menggunakan metode yang beragam, antara lain ceramah, latihan, dan diskusi. Namun metode tersebut belum dikembangkan secara optimal sehingga hasil belajar siswa belum maksimal. Hal tersebut ditunjukkan oleh metode pembelajaran yang digunakan membuat peran guru yang lebih dominan sehingga siswa belum semua terlihat aktif dalam proses pembelajaran. Guru lebih banyak menyampaikan materi dengan metode ceramah, kemudian siswa diberikan soal latihan. Hal tersebut menyebabkan proses pembelajaran belum maksimal dalam memberikan kesempatan kepada siswa untuk berpikir kritis dan bertindak kreatif. Pembelajaran seperti ini mengakibatkan siswa bekerja secara prosedural tanpa memahami konsep yang sebenarnya. Selain itu, pembelajaran yang masih terpaku pada buku pelajaran dan kurang terkait dengan kehidupan sehari-hari sehingga pembelajaran belum bisa dimaknai dengan siswa untuk memecahkan masalah matematika secara realistis khususnya dalam bentuk soal cerita.

Menurut Nasution (2017) "Metode pembelajaran sangat dibutuhkan dalam sekolah, khususnya bagi pembelajaran di dalam kelas". Hal ini sejalan dengan definisi metode pembelajaran dalam buku B. Uno \& Mohamad (2014) bahwa Metode pembelajaran didefinisikan sebagai cara yang digunakan guru dalam menjalankan fungsinya dan merupakan alat untuk mencapai tujuan pembelajaran. Berdasarkan permasalahan di atas, guru harus 
mampu merancang metode pembelajaran yang membuat siswa aktif, melatih kemampuan berpikirnya, dan memecahkan masalah matematika. Banyak metode yang dapat digunakan dalam proses pembelajaran, salah satunya adalah metode Problem Solving Model Polya.

Problem Solving dapat diartikan sebagai rangkaian aktivitas pembelajaran yang menekankan kepada proses penyelesaian masalah yang dihadapi secara ilmiah. Metode pemecahan masalah merupakan pembelajaran yang melibatkan siswa untuk aktif, kreatif dan mampu berfikir logis, kritis dan mampu berfikir tingkat tinggi dalam menyampaikan gagasannya untuk memecahkan suatu masalah yang dihadapinya. Berdasarkan data hasil penelitian yang dilakukan Setiyowati, Wijonarko, \& Sulianto (2018) bahwa diperoleh $\bar{x}_{\text {pretest }} 62,316$ dan $\bar{x}_{\text {posttest }} 73,105$, berdasarkan uji t-test diperoleh $t_{\text {hitung }} 5,543>t_{\text {tabel }}$ 2,09. Maka dapat disimpulkan bahwa ada perbedaan yang signifikan antara hasil belajar dalam kemampuan memcahkan masalah pretest dan posstest, nilai posttest lebih baik dari nilai pretest.

Berdasarkan uraian tersebut, dengan alasan yang rasional, pembelajaran dengan menggunakan metode Problem Solving Model Polya tepat digunakan dan diharapkan dapat meningkatkan kemampuan memecahkan masalah matematika. Karena dalam pembelajaran siswa dituntut untuk lebih aktif dalam memecahkan masalah metematika dengan menggunakan keterampilan dan pengetahuan serta langkah-langkah dalam penyelesaian masalah. Sehingga metode Problem Solving Model Polya ini juga dapat digunakan untuk meningkatkan hasil belajar siswa dalam memecahkan masalah matematika.

Berdasarkan uraian latar belakang diatas maka rumusan masalah dalam penelitian ini adalah: Apakah metode problem solving model polya efektif terhadap hasil belajar siswa dalam menyelesaiakan soal cerita matematika? Bagaimana efektivitas metode problem solving model polya terhadap hasil belajar siswa dalam menyelesaikan soal cerita matematika?

\section{B. METODE}

Jenis penelitian ini adalah penelitian PreExperimental. Adapun rancangan penelitian ini berbentuk One Group Pretest-Posttest Design dengan menggunakan perlakuan pada objek penelitian dengan melibatkan satu kelas saja sebagai kelas eksperimen tanpa variabel kontrol. Perlakuan yang dimaksud adalah penggunaan metode problem solving model polya dalam memecahkan masalah soal cerita matematika. Sebagaimana disajikan pada table berikut.

Table 1. Rancangan Penelitian Pre-Eksperimental

\begin{tabular}{ccc}
\hline Tes Awal & Perlakuan & Tes Akhir \\
\hline $\mathrm{T}_{1}$ & $\mathrm{X}$ & $\mathrm{T}_{2}$ \\
\hline & \multicolumn{2}{c}{ (Nasir, Upu, \& Hisyam, 2016) }
\end{tabular}


Keterangan:

$\mathrm{T}_{1}$ : Tes awal (pretest), tes sebelum perlakuan.

$\mathrm{T}_{2}$ : Tes akhir (posttest), tes setelah perlakuan

X : Metode Problem solving model Polya

Prosedur:

1. Memberikan tes sebelum perlakuan (pretest) dalam hal ini $\mathrm{T}_{1}$, yaitu untuk mengukur mean pemahaman konsep metode problem solving model polya sebelum subjek diajar dengan menggunakan metode problem solving model polya.

2. Memberikan perlakuan kepada subjek dalam hal ini $X$, yaitu Metode pembelajaran Problem solving model Polya

3. Memberikan tes sesudah dilakukan perlakuan (post test) dalam hal ini $\mathrm{T}_{2}$, untuk mengukur mean pemahaman konsep materi setelah subjek dikenakan variabel eksperimental X.

4. Bandingkan $T_{1}$ dan $T_{2}$ untuk menentukan seberapakah perbedaan yang timbul, jika sekiranya ada, sebagai akibat dari digunakannya variabel eksperimental X.

5. Terapkan test statistik yang cocok dalam hal ini t-test untuk menentukan apakah perbedaan itu signifikan.

Penelitian ini dilaksanakan pada semester genap tahun ajaran 2018/2019 tepatnya pada bulan Februari - April 2019. Penelitian ini dilaksanakan di SMA Negeri 11 Maros Baru yang beralamat di Pangkasalo Kel. Baju Bodoa, Kec. Maros Baru, Kab. Maros. Populasi pada penelitian ini adalah peserta didik kelas X SMA Negeri 11 Maros Baru tahun ajaran 2018/2019 yang berjumlah 160 siswa. Sampel yang digunakan pada penelitian ini adalah satu kelas dari kelas X SMA Negeri 11 Maros Baru yaitu kelas X B yang menggunakan pembelajaran dengan metode problem solving model polya yang berjumlah 28 orang dengan jumlah siswa perempuan 18 orang dan jumlah siswa laki-laki 10 orang. Adapun teknik pengambilan sampelnya yaitu Simple Random Sampling.

Variabel bebas (variable independen) pada penelitian ini yaitu metode pembelajaran problem solving model polya. Variabel terikat (variable dependen) pada penelitian ini yaitu hasil belajar siswa dalam memecahkan masalah soal cerita matematika.

Data hasil belajar peserta didik dikumpulkan melalui pemberian tes. Tes yang diberikan 2 kali, yaitu sebelum dan sesudah perlakuan. Tes yang diberikan adalah tes yang telah divalidasi. Adapun hasil belajar peserta didik diperoleh akan dianalisis secara statistik deskriptif dan statistik inferensial

\section{HASIL PENELITIAN}

Berdasarkan analisis data yang diperoleh maka hasil penelitian ini meliputi: data aktivitas siswa selama proses pembelajaran, data kemampuan guru dalam mengelola pembelajaran, data respon siswa dan data ketuntasan hasil belajar siswa setelah proses pembelajaran dengan menggunakan metode problem solving model Polya dalam menyelesaikan soal cerita matematika. 


\section{Aktivitas Siswa}

Data tentang aktivitas siswa diambil dari pengamatan yang dilakukan oleh satu orang pengamat yaitu peneliti. Pengamatan dilakukan selama proses pembelajaran berlangsung selama tiga kali pertemuan. Persentase dan rata-rata aktivitas siswa untuk setiap indikator terangkum dalam tabel 2 berikut:

Tabel 2. Hasil Aktivitas Siswa Selama Kegiatan Pembelajaran

\begin{tabular}{|c|c|c|c|c|c|c|c|c|c|}
\hline \multirow[t]{2}{*}{ NO } & \multirow[t]{2}{*}{ Aktivitas Siswa } & \multicolumn{3}{|c|}{$\begin{array}{c}\text { Frekuensi } \\
\text { Banyaknya } \\
\text { Siswa } \\
\end{array}$} & \multicolumn{3}{|c|}{ Persentase (\%) } & \multirow{2}{*}{$\begin{array}{l}\text { Rata- } \\
\text { rata } \\
(\%)\end{array}$} & \multirow{2}{*}{$\begin{array}{c}\text { Jumlah } \\
\text { (\%) }\end{array}$} \\
\hline & & P1 & $\mathbf{P 2}$ & P3 & P1 & P2 & P3 & & \\
\hline \multirow{8}{*}{1} & Aktivitas aktif & & & & & & & & 79.87 \\
\hline & Menyelesaikan soal & 15 & 20 & 25 & 10.49 & 14.60 & 18.25 & 14.45 & \\
\hline & $\begin{array}{l}\text { Membuat atau melengkapi } \\
\text { catatan }\end{array}$ & 25 & 21 & 24 & 17.48 & 15.33 & 17.52 & 16.78 & \\
\hline & $\begin{array}{l}\text { Menyampaikan pendapat } \\
\text { memberikan penjelasan } \\
\text { secara lisan }\end{array}$ & 10 & 9 & 11 & 6.99 & 6.57 & 8.03 & 7.20 & \\
\hline & $\begin{array}{l}\text { Berdiskusi atau bertanya } \\
\text { pada teman atau guru }\end{array}$ & 7 & 15 & 13 & 4.90 & 10.95 & 9.49 & 8.44 & \\
\hline & $\begin{array}{l}\text { Mengajukan pertanyaan } \\
\text { atau meminta penjelasan } \\
\text { guru dan teman }\end{array}$ & 9 & 3 & 5 & 6.29 & 2.19 & 3.65 & 4.04 & \\
\hline & $\begin{array}{l}\text { Mendengarkan atau } \\
\text { memperhatikan penjelasan } \\
\text { teman }\end{array}$ & 21 & 17 & 19 & 14.69 & 12.41 & 13.87 & 13.65 & \\
\hline & Kegiatan lain dalam tugas & 26 & 21 & 17 & 18.18 & 15.33 & 12.41 & 15.31 & \\
\hline \multirow{3}{*}{2} & Aktivitas Pasif & & & & & & & & 20.13 \\
\hline & $\begin{array}{l}\text { Mendengarkan atau } \\
\text { memperhatikan penjelasan } \\
\text { guru }\end{array}$ & 23 & 25 & 21 & 16.08 & 18.25 & 15.33 & 16.55 & \\
\hline & Kegiatan lain di luar tugas & 7 & 6 & 2 & 4.90 & 4.38 & 1.46 & 3.58 & \\
\hline & Jumlah & 143 & 137 & 137 & 100.00 & 100.00 & 100.00 & 100.00 & 100.00 \\
\hline
\end{tabular}

Berdasarkan hasil aktivitas siswa di atas, kategori aktivitas aktif memperoleh persentase sebesar 79,87 \% dan untuk kategori aktivitas pasif memperoleh persentase sebesar $20,13 \%$. Sesuai dengan kriteria keefektifan, aktivitas siswa selama pembelajaran dengan metode problem solving model Polya dalam menyelesaikan soal cerita matematika dikatakan efektif. 
2. Kemampuan Guru dalam Mengelola pengamatan yang dilakukan oleh peneliti Pembelajaran selama tiga kali pertemuan. Hasil pengamatan

Data tentang kemampuan guru dalam terangkum dalam tabel 3 sebagai berikut: mengelola pembelajaran diambil dari

Tabel 3. Hasil Pengamatan Kemampuan Guru Mengelola Pembelajaran dengan Metode Problem Solving Model Polya

\begin{tabular}{|c|c|c|c|c|c|c|c|}
\hline No & Aspek yang Diamati & P1 & $\mathbf{P 2}$ & P3 & $\begin{array}{l}\text { Rata- } \\
\text { Rata }\end{array}$ & $\begin{array}{l}\text { Rata- rata } \\
\text { Tiap Aspek }\end{array}$ & Kategori \\
\hline $\mathbf{I}$ & PERSIAPAN ( secara keseluruhan) & 4 & 4 & 4 & 4 & 4 & Sangat Baik \\
\hline \multirow[t]{20}{*}{ II } & PELAKSANAAN & - & - & - & - & - & - \\
\hline & Pendahuluan & - & - & - & - & 3,33 & Baik \\
\hline & Menyampaikan tujuan pembelajaran & 3 & 3 & 3 & 3 & & \\
\hline & Memotivasi siswa & 4 & 3 & 4 & 3,67 & & \\
\hline & Kegiatan Inti & & & & & 3,25 & Baik \\
\hline & $\begin{array}{l}\text { Guru menggambarkan materi yang akan } \\
\text { dipelajari }\end{array}$ & 3 & 3 & 3 & 3 & & \\
\hline & Guru menjelaskan materi & 3 & 4 & 3 & 3,33 & & \\
\hline & $\begin{array}{l}\text { Guru memberikan kesempatan kepada } \\
\text { siswa untuk bertanya }\end{array}$ & 3 & 2 & 3 & 2,67 & & \\
\hline & Guru menanggapi pertanyaan siswa & 4 & 4 & 3 & 3,67 & & \\
\hline & Guru memberikan contoh soal & 3 & 3 & 4 & 3,33 & & \\
\hline & $\begin{array}{l}\text { Memberi soal tentang materi sebagai } \\
\text { latihan. }\end{array}$ & 4 & 4 & 4 & 4 & & \\
\hline & $\begin{array}{l}\text { Menanggapi dan membenahi jawaban } \\
\text { yang salah. }\end{array}$ & 4 & 3 & 3 & 3,33 & & \\
\hline & $\begin{array}{l}\text { Mengecek pemahaman siswa terhadap } \\
\text { soal yang diberikan. }\end{array}$ & 3 & 2 & 3 & 2,67 & & \\
\hline & Penutup & - & - & - & - & 3,17 & Baik \\
\hline & $\begin{array}{l}\text { Mereview kembali materi yang telah } \\
\text { dipelajari dengan melihat peta pikiran }\end{array}$ & 3 & 3 & 3 & 3 & & \\
\hline & $\begin{array}{l}\text { Guru menjelaskan secara singkat materi } \\
\text { sebagai teknik mencatat yang efektif yang } \\
\text { bisa digunakan oleh siswa }\end{array}$ & 3 & 3 & 3 & 3 & & \\
\hline & $\begin{array}{l}\text { Membimbing siswa membuat rangkuman } \\
\text { sesuai dengan kreativitas mereka masing- } \\
\text { masing. }\end{array}$ & 3 & 4 & 4 & 3,67 & & \\
\hline & $\begin{array}{l}\text { Guru melihat kembali rangkuman untuk } \\
\text { memberikan informasi materi yang akan } \\
\text { dipelajari pada pertemuan selanjutnya }\end{array}$ & 3 & 4 & 4 & 3,67 & & \\
\hline & Memberikan tugas rumah. & 2 & 3 & 3 & 2,67 & & \\
\hline & Menutup pembelajaran. & 3 & 3 & 3 & 3 & & \\
\hline III & PENGELOLAAN WAKTU & 3 & 3 & 4 & 3,33 & 3,33 & Baik \\
\hline
\end{tabular}




\begin{tabular}{|c|c|c|c|c|c|c|c|}
\hline No & Aspek yang Diamati & P1 & $\mathbf{P 2}$ & P3 & $\begin{array}{l}\text { Rata- } \\
\text { Rata }\end{array}$ & $\begin{array}{l}\text { Rata- rata } \\
\text { Tiap Aspek }\end{array}$ & Kategori \\
\hline \multirow[t]{4}{*}{ IV } & SUASANA KELAS & - & - & - & - & 2,89 & Baik \\
\hline & Berpusat pada siswa & 3 & 3 & 3 & 3 & & \\
\hline & Siswa antusias & 2 & 3 & 3 & 2,67 & & \\
\hline & Guru antusias & 3 & 3 & 3 & 3 & & \\
\hline \multicolumn{2}{|c|}{ RATA-RATA } & & & & & 3,19 & Baik \\
\hline
\end{tabular}

Keterangan: P1 = Pertemuan I; P2 = Pertemuan II; P3 = Pertemuan III

Berdasarkan tabel 3 di atas diperoleh nilai rata- rata keseluruhan aspek adalah 3,19. Sesuai kriteria keefektifan, kemampuan guru dalam mengelola pembelajaran dengan metode problem solving model Polya dalam menyelesaikan soal cerita matematika dikatakan efektif.

\section{Respon Siswa}

Data tentang respon siswa terhadap kegiatan belajar mengajar diperoleh dari angket yang dibagikan kepada setiap siswa. Hasil respon siswa terhadap kegiatan belajar mengajar terangkum dalam tabel 4. sebagai berikut:

Tabel 4. Respon Siswa terhadap Kegiatan Pembelajaran

\begin{tabular}{|c|c|c|c|c|c|}
\hline \multirow[b]{2}{*}{ NO } & \multirow[b]{2}{*}{ ASPEK YANG DITANYAKAN } & \multicolumn{2}{|c|}{ Respon Siswa } & \multicolumn{2}{|c|}{ Persentase (\%) } \\
\hline & & Senang & $\begin{array}{l}\text { Tidak } \\
\text { Senang }\end{array}$ & Senang & $\begin{array}{c}\text { Tidak } \\
\text { Senang }\end{array}$ \\
\hline 1 & $\begin{array}{l}\text { Bagaimana perasaanmu selama mengikuti } \\
\text { pembelajaran ini? }\end{array}$ & 25 & 3 & 89.29 & 10.71 \\
\hline 2 & $\begin{array}{l}\text { Bagaimana perasaanmu terhadap cara guru mengajar } \\
\text { selama pembelajaran? }\end{array}$ & 23 & 5 & 82.14 & 17.86 \\
\hline & KATEGORI & Menarik & $\begin{array}{c}\text { Tidak } \\
\text { Menarik }\end{array}$ & Menarik & $\begin{array}{c}\text { Tidak } \\
\text { Menarik }\end{array}$ \\
\hline 3 & $\begin{array}{l}\text { Bagaimana pendapatmu tentang metode problem } \\
\text { solving model Polya yang dibawakan oleh guru? }\end{array}$ & 24 & 4 & 85.71 & 14.29 \\
\hline 4 & $\begin{array}{l}\text { Bagaimana pendapatmu tentang materi pelajaran } \\
\text { yang diajarkan di kelas? }\end{array}$ & 19 & 9 & 67.86 & 32.14 \\
\hline & KATEGORI & Ya & Tidak & Ya & Tidak \\
\hline 5 & $\begin{array}{l}\text { Apakah guru matematika kalian memberikan topik } \\
\text { dengan jelas ketika kalian disuruh mengerjakan tugas? }\end{array}$ & 19 & 9 & 67.86 & 32.14 \\
\hline 6 & $\begin{array}{l}\text { Apakah dengan metode problem solving model Polya, } \\
\text { kamu lebih mudah memahami materi dengan baik? }\end{array}$ & 20 & 8 & 71.43 & 28.57 \\
\hline 7 & $\begin{array}{l}\text { Apakah kamu berminat untuk mengikuti kegiatan } \\
\text { belajar mengajar berikutnya seperti yang telah kamu } \\
\text { ikuti tadi? }\end{array}$ & 26 & 2 & 92.86 & 7.14 \\
\hline 8 & $\begin{array}{l}\text { Apakah dalam mengerjakan tugas dari guru } \\
\text { matematika, kamu merasakan kemudahan? }\end{array}$ & 20 & 8 & 71.43 & 28.57 \\
\hline
\end{tabular}




\begin{tabular}{ccccc}
\hline \multirow{2}{*}{ NO } & ASPEK YANG DITANYAKAN & \multicolumn{2}{c}{ Respon Siswa } & \multicolumn{2}{c}{ Persentase (\%) } \\
\cline { 2 - 5 } & Senang & $\begin{array}{c}\text { Tidak } \\
\text { Senang }\end{array}$ & Senang & $\begin{array}{c}\text { Tidak } \\
\text { Senang }\end{array}$ \\
\hline $\begin{array}{l}\text { Apakah dengan mengunakan metode problem solving } \\
\text { model Polya kamu lebih mudah mengingat materi } \\
\text { yang telah kamu pelajari? }\end{array}$ & 21 & 7 & 75.00 & 25.00 \\
\hline $\begin{array}{l}\text { Setelah mengikuti pembelajaran dengan } \\
\text { menggunakan metode problem solving model Polya, } \\
\text { apakah matematika merupakan pelajaran yang } \\
\text { menarik? }\end{array}$ & 22 & 6 & 78.57 & 21.43 \\
\hline RATA-RATA (\%) & & $\mathbf{7 8 . 2 1}$ & $\mathbf{2 1 . 7 9}$ \\
\hline
\end{tabular}

Berdasarkan tabel 4 di atas rata-rata persentase respon siswa untuk tiap aspek senang dan ya lebih dari $65 \%$. Sesuai dengan kriteria keefektifan, respon siswa terhadap pembelajaran metode problem solving model Polya dalam menyelesaikan soal cerita matematika dikatakan positif.

\section{Hasil Belajar Siswa}

Data tentang hasil belajar siswa diperoleh dari skor tes akhir yang diberikan kepada siswa di akhir pertemuan. Berdasarkan data hasil belajar diperoleh hasil belajar siswa dari 28 siswa yang mengikuti tes akhir, 5 orang siswa tidak tuntas sedangkan 23 siswa lainnya tuntas dengan tingkat ketuntasan belajar secara klasikal adalah 82,14 \%. Berdasarkan kriteria keefektifan, tes hasil belajar siswa dikatakan tuntas.

Pencapaian keefektifan metode pembelajaran metode problem solving model Polya dalam menyelesaikan soal cerita matematika ditentukan berdasarkan data dari aktivitas siswa, pengelolaan guru, respon siswa dan hasil belajar selama kegiatan pembelajaran berlangsung. Daftar pencapaian keefektifan metode problem solving model Polya dalam menyelesaikan soal cerita matematika terangkum dalam tabel 5 .

Tabel 5. Pencapaian keefektifan metode pembelajaran peta pikiran

\begin{tabular}{|c|c|c|}
\hline No & Aspek yang diamati & Kesimpulan \\
\hline 1 & $\begin{array}{l}\text { Aktivitas siswa dalam } \\
\text { pembelajaran dengan } \\
\text { metode problem solving } \\
\text { model Polya dalam } \\
\text { menyelesaikan soal cerita } \\
\text { matematika }\end{array}$ & Efektif \\
\hline 2 & $\begin{array}{l}\text { Kemampuan guru } \\
\text { mengelola pembelajaran } \\
\text { dengan metode problem } \\
\text { solving model Polya } \\
\text { dalam menyelesaikan } \\
\text { soal cerita matematika }\end{array}$ & Efektif \\
\hline 3 & $\begin{array}{l}\text { Respon siswa terhadap } \\
\text { pembelajaran dengan } \\
\text { metode problem solving } \\
\text { model Polya dalam } \\
\text { menyelesaikan soal cerita } \\
\text { matematika }\end{array}$ & Positif \\
\hline 4 & $\begin{array}{l}\text { Ketuntasan belajar siswa } \\
\text { pada pembelajaran } \\
\text { dengan metode problem } \\
\text { solving model Polya } \\
\text { dalam menyelesaikan } \\
\text { soal cerita matematika } \\
\end{array}$ & Tuntas \\
\hline $\mathrm{Be}$ & $\begin{array}{l}\text { dasarkan tabel } 5 \text { di } \\
\text { ulkan bahwa pembelaj }\end{array}$ & $\begin{array}{l}\text { atas dapat } \\
\text { ran dengan }\end{array}$ \\
\hline
\end{tabular}


metode problem solving model Polya dalam menyelesaikan soal cerita matematika dikatakan efektif. Sesuai dengan kriteria keefektifan, suatu pembelajaran dikatakan efektif jika paling sedikit tiga dari aspek di atas dipenuhi, dengan syarat aspek aktivitas siswa efektif dan hasil belajar klasikal tuntas terpenuhi.

\section{PEMBAHASAN}

Dari hasil pengamatan yang dilakukan peneliti sebanyak tiga kali pertemuan melalui pengamatan (observasi) dan sebaran angket, diperoleh beberapa hasil pengamatan yang berdasarkan tabel aktivitas siswa, kemampuan guru dalam mengelola pembelajaran, respon siswa dan ketuntasan belajar siswa selama pembelajaran dengan menggunakan metode problem solving model Polya dalam menyelesaikan soal cerita matematika. Adapun hasil dari pengamatan dalam penelitian ini adalah sebagai berikut:

\section{Aktivitas Siswa}

Berdasarkan hasil pengamatan kegiatan belajar mengajar selama menggunakan metode peta pikiran, dapat dilihat bahwa aktivitas yang sering dilakukan siswa selama proses belajar mengajar adalah membuat atau melengkapi catatan dengan rata-rata persentase $16.78 \%$. Hal ini disebabkan pada pembelajaran dengan metode problem solving model Polya dalam menyelesaikan soal cerita matematika siswa dikondisikan belajar melalui sebuah permasalahan yang kemudian siswa dituntut untuk memecahkannya dengan model Polya berdasarkan kreasi mereka masing-masing.

Aktivitas siswa lainnya yang cukup sering dilakukan siswa saat pembelajaran dengan metode problem solving model Polya dalam menyelesaikan soal cerita matematika berlangsung adalah mendengarkan atau memperhatikan penjelasan guru dengan persentase $16.55 \%$. Hal ini disebabkan karena model pembelajaran yang dibawakan oleh guru adalah model pembelajaran langsung yang masih berpusat pada penjelasan guru.

Aktivitas lain yang cukup sering juga dilakukan oleh siswa pada saat pembelajaran berlangsung adalah kegiatan lain dalam tugas yaitu menunjukkan gerakan seperti sedang berfikir pada saat guru menjelaskan, yang memiliki persentase $15.31 \%$. Hal ini disebabkan karena pembelajaran dengan menggunakan metode problem solving model Polya, siswa dirangsang berfikir untuk memahami materi yang disajikan melalui pemecahan masalah. Tetapi jika diamati pada tiap pertemuan, aktivitas siswa dengan kategori kegiatan lain dalam tugas mengalami penurunan. Hal itu ditunjukkan pada pertemuan pertama dengan nilai $18,18 \%$, pada pertemuan kedua dengan nilai 15,33 \% dan pada pertemuan ketiga dengan nilai $12,41 \%$. Hal itu disebabkan karena pada pertemuan I siswa pertama kali meliahat peta pikiran yang disajikan oleh guru sehingga siswa lebih antusias, sedangkan pada pertemuan II dan III yang disajikan hanyalah berupa lanjutan peta pikiran dari pertemuan I. 
Sedangkan pada aktivitas siswa dengan kategori menyelesaikan soal mengalami peningkatan, hal itu ditunjukkan pada pertemuan pertama dengan nilai $10,49 \%$, pada pertemuan kedua dengan nilai $14,60 \%$, dan pada pertemuan ketiga dengan nilai 18,25\%. Hal itu disebabkan karena guru menyajikan materi dengan jelas melalui peta pikiran, sehingga lebih mudah bagi siswa untuk mengingat dan memahami materi yang telah dipelajari yang kemudian memudahkan siswa untuk menyelesaikan soal.

Dari seluruh kategori aktivitas aktif diperoleh persentase sebesar 79,87 \% dan untuk kategori aktivitas pasif diperoleh sebesar $20.13 \%$. Sesuai dengan kriteria keefektifan, jika persentase aktivitas aktif lebih besar daripada aktivitas pasif. Maka dapat disimpulkan bahwa aktivitas siswa selama pembelajaran dengan metode problem solving model Polya dalam menyelesaikan soal cerita matematika dikatakan efektif.

\section{Kemampuan Guru dalam Mengelola Pembelajaran}

Berdasarkan hasil pengamatan penelitian, maka dapat diketahui bahwa dalam mengelola pembelajaran yang menggunakan metode problem solving model Polya dalam menyelesaikan soal cerita matematikaguru melakukan pembelajaran dengan baik. Hal itu terlihat pada aspek persiapan dengan nilai ratarata 4,00 yang menunjukkan bahwa persiapan yang dilakukan oleh guru secara keseluruhan dari penataan lingkungan kelas sampai instrumen yang mendukung dalam metode problem solving model Polya dalam menyelesaikan soal cerita matematika adalah sangat baik.

Untuk aspek pendahuluan nilai rata-rata yang diperoleh adalah 3,33. Hal ini menunjukkan bahwa kemampuan guru dalam menyampaikan tujuan pembelajaran dan memotivasi siswa terkategori baik. Langkah selanjutnya setelah memotivasi siswa adalah menyajikan materi dengan metode problem solving model Polya dalam menyelesaikan soal cerita matematikayang dilakukan guru pada kegiatan inti. Nilai rata-rata untuk aspek kegiatan inti adalah 3,25. Sehingga dapat diartikan bahwa guru melaksanakan pembelajaran dengan metode problem solving model Polya dalam menyelesaikan soal cerita matematikadengan baik.

Kegiatan guru pada aspek penutup nilai rataratanya adalah 3,17. Hal ini menunjukkan bahwa guru menutup pembelajaran dengan baik. Nilai rata-rata untuk pengelolaan waktu adalah 3,33 yang menunjukkan bahwa dalam mengelola waktu pembelajaran, guru melakukannya dengan baik. Sedangkan untuk nilai rata-rata aspek suasana kelas adalah 2,89. Hal ini menunjukkan bahwa guru dapat memberikan suasana kelas yang cukup baik.

Dari keseluruhan aspek diperoleh nilai ratarata 3,19. Jadi, untuk kemampuan guru dalam mengelola pembelajaran dengan metode problem solving model Polya dalam menyelesaikan soal cerita matematika 
termasuk dalam kategori baik. Sesuai dengan kriteria keefektifan bahwa kemampuan guru dalam mengelola pembelajaran dikatakan efektif jika mencapai kriteria baik. Maka dapat disimpulkan bahwa kemampuan guru dalam mengelola pembelajaran dengan metode problem solving model Polya dalam menyelesaikan soal cerita matematikadikatakan efektif.

\section{Respon Siswa}

Berdasarkan hasil pengamatan yang ada, maka dapat diketahui bahwa minat siswa terhadap pembelajaran dengan menggunakan metode problem solving model Polya dalam menyelesaikan soal cerita matematika sangat positif. Siswa mengharapkan pembelajaran dengan metode problem solving model Polya dalam menyelesaikan soal cerita matematika ini bisa diterapkan kembali, karena dengan pembelajaran seperti ini mereka dapat dengan mudah mengingat dan memahami materi yang diajarkan oleh guru.

\section{Ketuntasan Hasil Belajar Siswa}

Berdasarkan hasil penelitian dari 28 siswa yang mengikuti tes akhir, 5 orang siswa tidak tuntas sedangkan 23 siswa lainnya tuntas dengan tingkat ketuntasan belajar secara klasikal adalah 82,14\%. Hal yang menyebabkan 5 orang siswa tidak tuntas adalah karena mereka belum memahami materi yang diajarkan dan sering tidak serius dalam menerima pelajaran.
Berdasarkan kriteria ketuntasan belajar klasikal SMA Negeri 11 Maros Baruyaitu jika siswa dalam kelas telah mencapai ketuntasan belajar sebesar $\geq 75 \%$ maka hasil belajar secara klasikal pada sub materi persamaan linier tiga variabel dikatakan tuntas. Pembelajaran dengan metode problem solving model Polya dalam menyelesaikan soal cerita matematikapada penelitian ini memiliki ketuntasan belajar klasikal sebesar 82,14\% dan melebihi standar yang dimiliki oleh sekolah yaitu lebih dari sama dengan $75 \%$. Sehingga pembelajaran dengan metode problem solving model Polya dalam menyelesaikan soal cerita matematikapada materi pokok persamaan linier tiga variabel secara klasikal dikatakan tuntas.

Pencapaian keefektifan metode problem solving model Polya dalam menyelesaikan soal cerita matematikadalam pembelajaran matematika ditentukan berdasarkan data dari aktivitas siswa, kemampuan guru dalam mengelola pembelajaran, respon siswa, dan ketuntasan hasil belajar siswa selama kegiatan pembelajaran berlangsung.

Berdasarkan uraian pembahasan di atas dapat dilihat bahwa aktivitas siswa selama pembelajaran menggunakan metode problem solving model Polya dalam menyelesaikan soal cerita matematika dikategorikan aktif, untuk kemampuan guru dalam mengelola pembelajaran menggunakan metode problem solving model Polya dikatakan baik, respon siswa terhadap pembelajaran menggunakan metode problem solving model Polya dalam 
menyelesaikan soal cerita matematika dikategorikan positif, sedangkan untuk hasil ketuntasan siswa secara klasikal pada pembelajaran yang menggunakan metode problem solving model Polya dalam menyelesaikan soal cerita matematikajuga dikategorikan tuntas. Sesuai dengan syarat keefektifan pembelajaran yaitu suatu pembelajaran dikatakan efektif jika dari empat aspek yang ditentukan telah dipenuhi, dengan syarat satu dan empat harus dipenuhi, maka dari uraian hasil penelitian dan pembahasan diatas dapat dikatakan bahwa pembelajaran menggunakan metode problem solving model Polya dalam menyelesaikan soal cerita matematikapada materi pokok persamaan linear tiga variabel kelas X SMA Negeri 11 Maros Baru dikatakan efektif.

\section{E. PENUTUP}

\section{Kesimpulan}

Berdasarkan hasil analisis data penelitian diperoleh simpulan bahwa penggunaan metode problem solving model dalam menyelesaikan soal cerita matematika secara umum dapat dikatakan efektif yang dapat dilihat dari empat aspek, yaitu :

a. Aktivitas siswa selama proses pembelajaran dikategorikan aktif dengan persentase sebesar $79,87 \%$.

b. Kemampuan guru dalam mengelola pembelajaran dapat dikategorikan baik dengan nilai rata-rata keseluruhan aspeknya adalah sebesar 3,19. c. Respon siswa selama pembelajaran dikategorikan positif dengan rata-rata persentase jawaban senang, menarik, dan ya adalah sebesar $78,21 \%$

d. Ketuntasan hasil belajar siswa terhadap pembelajaran dapat dikatakan tuntas dengan persentase ketuntasan klasikalnya sebesar $82,14 \%$

\section{Saran}

Berdasarkan penelitian yang telah dilakukan, maka peneliti memberikan saran kepada semua pihak agar melakukan penelitian pengembangan lebih lanjut terkait metode pembelajaran problem solving model Polya agar pengetahuan tidak berhenti sampai disini.

\section{DAFTAR PUSTAKA}

Akhriani. (2014). Komparasi Keefektifan Pendekatan Problem Posing dan pendekatan Problem Solving dalam Pembelajaran Matematika Pada siswa Kelas VIII A SMP LPP Umi Makasar. PPS UNM .

B. Uno, H., \& Mohamad, N. (2014). Belajar dengan Pendekatan Pailkem: Pembelajaran Aktif, inivatif, lingkungan, Kreatif, efektif, Menarik. Jakarta: Bumi Aksara.

Biga, N. (2013). Deskripsi Bentuk-Bentuk Kesalahan Dalam Menyelesaikan Soal Cerita Volum Kubus dan Balok Pada Siswa Kelas V SDN 1 Suwawa Selatan Kabupaten Bone Bulango. Skripsi tidak dipublikasikan.

Dewi, S. K., Suardjana, \& Sumantri. (2014). Penerapan Polya untuk Meningkatkan Hasil Belajar dalam Memecahkan Soal Cerita Matematika Siswa Kelas V. Jurnal Mimbar 
PGSD Universitas Pendidikan Ganesha Jurusan PGSD , 2 (1), 77-89.

Ernawati, \& Nasir, A. M. (2018). Efektivitas Metode Pembelajaran Sochrates Kontekstual Berbasis Gaya Kognitif Terhadap Hasil Belajar Statistik Dasar. Jurnal Penelitian Matematika dan Pendidikan Matematika , 1 (2), 31-44.

Nasir, A., Upu, H., \& Hisyam, I. (2016). Penerapan Media Animasi pada Materi Bangun Datar Segiempat Dalam
Pembelajaran Matematika Kelas VII SMP. Ecosystem , 16 (3), 477-488.

Nasution, M. K. (2017). Penggunaan Metode Pembelajaran Dalam Peningkatan Hasil Belajar Siswa. STUDIA DIDAKTIKA: Jurnal IImiah Bidang Pendidikan , 11 (1), 9-16.

Setiyowati, L., Wijonarko, \& Sulianto, J. (2018). Penerapan Metode Problem Solving Model Polya Terhadap Kemampuan Memecahkan Masalah Pada Materi Operasi Hitung Campuran Kelas 3 SD. Jurnal Sekolah (JS) , 2 (2), 32-37. 